\title{
Small red scorpionfish Scorpaena notata Rafinesque, 1810 (Actinopterygii: Scorpaenidae) - an unknown species for the Bulgarian Black Sea coast
}

\author{
Tihomir Stefanov \\ National Museum of Natural History, Bulgarian Academy of Sciences, 1 Tsar Osvoboditel Blvd, 1000 Sofia, Bulgaria, \\ tishos@gmail.com; https://orcid.org/0000-0003-1084-8358
}

\begin{abstract}
One adult specimen of small red scorpionfish Scorpaena notata Rafinesque, 1810 was found in the ichthyological collections of the National Museum of Natural History in Sofia, Bulgaria. The specimen has been caught on 12 May 1926 in Black Sea near the town of Burgas and labelled as Scorpaena porcus. This is the first finding of the species along the Bulgarian Black Sea coast and the oldest record in the Black Sea.
\end{abstract}

Keywords: Black Sea, Bulgaria, museum collections, Scorpaena notata, Scorpaenidae

\section{Introduction}

The small red scorpionfish Scorpaena notata Rafinesque, 1810, is a small-sized benthic fish from the family Scorpaenidae. It is usually occurred in crevices of rocky coastal habitats on depths between 10-50 meters but rarely could be found up to 700 meters (Muñoz et al., 2005). The species is distributed in the Mediterranean Sea and adjacent areas of the eastern Atlantic, Madeira, Azores, the Canary Islands and the north-western coast of Africa south to Senegal (Eschmayer, 1969). It occurred also in the Aegean Sea and the Sea of Marmara (Bilecenoglu et al., 2002; Fricke et al., 2007). The species was found for the first time in the Black Sea in 1930 near Gelendzhik, Russia (see Svetovidov, 1964) and few years later described as new taxon - Scorpaena scrofa afimbria Slastenenko, 1935 (see Svetovidov, 1964; Hureau \& Litvinenko, 1986). Although it was described as an infrasubspecific taxon, which makes the name unavailable, the combination Scorpaena afimbria was later used by Svetovidov (1964). According to him the species is known in the
Black Sea only near Gelendzhik and Novorosiysk on the north-east coast. Nowadays S. afimbria is treated as a junior synonym of $S$. notata (Fricke et al., 2021) and it is known that its distribution in the Black Sea covers the coasts of Romania, Russian Federation, Turkey and Ukraine (Bilecenoglu et al., 2002; Fricke et al., 2007; Vasil'eva, 2007; Maximov \& Zaharia, 2010; Yankova et al., 2014). The species is still unknown from the Bulgarian sector.

\section{Material and methods}

One adult specimens of $S$. notata $(132.5 \mathrm{~mm} \mathrm{Tl})$ was found in the ichthyological collections of the National Museum of Natural History in Sofia, Bulgaria. The specimen was caught on 12 May 1926 in the Black Sea near the town of Burgas and stored in formaline. It is labelled as Scorpaena porcus under Inv. No. NMNHSF 000110 (old Inv. No. 98/5). The specimen is in very good condition and the body shape and coloration are well preserved and suitable for species determination 


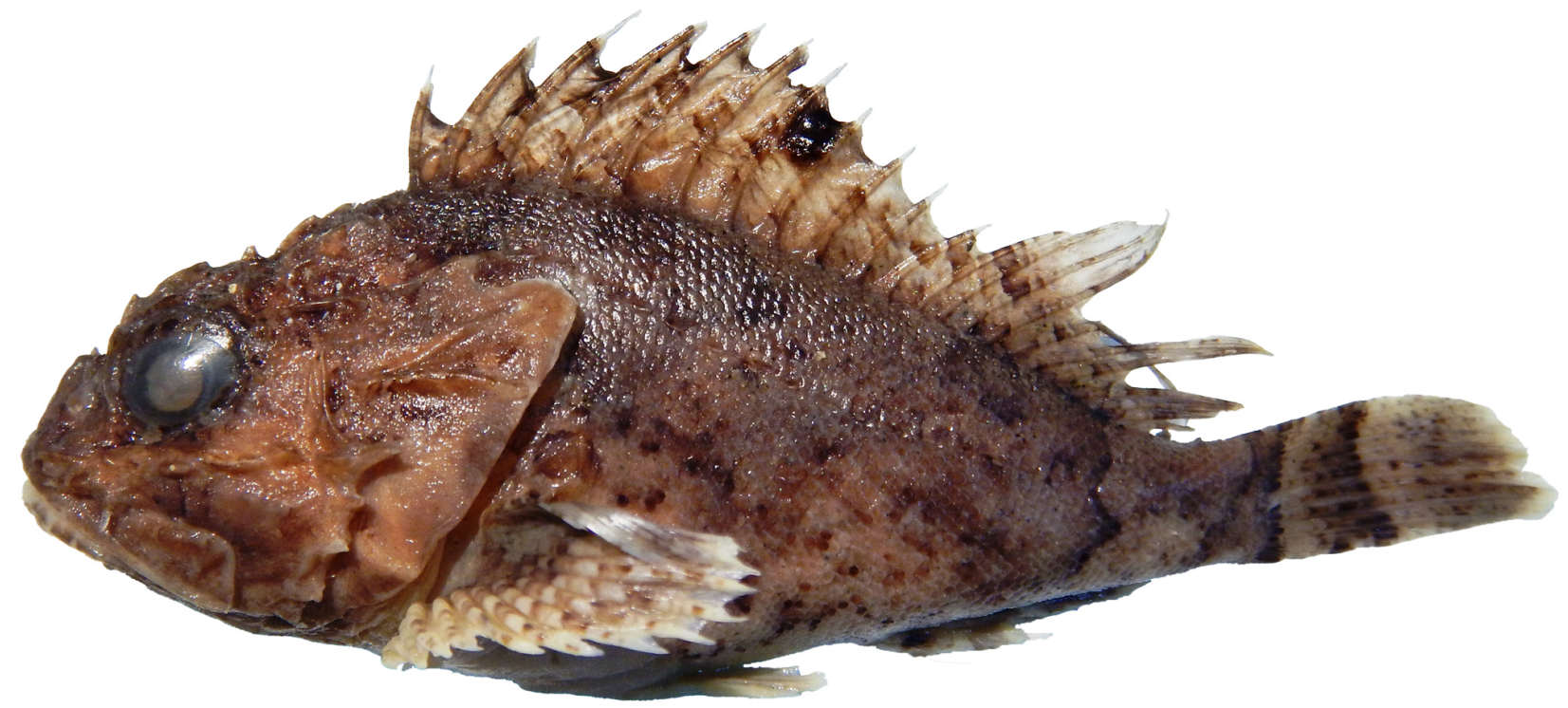

Fig. 1. S. notata $(132,5 \mathrm{~mm} \mathrm{Tl})$ found in the ichthyological collections of the National Museum of Natural History, Sofia (Inv. No. NMNHS-F 000110): lateral view of the body.

(Fig. 1). The specimen was measured with an electronic caliper as all measurements were made point-topoint and recorded to the nearest of $0.1 \mathrm{~mm}$. Method for counting fin rays and scales as well as all methods for measurements generally follow Kottelat \& Freyhof (2007).

\section{Results and discussion}

The studied specimen had been initially determined and labelled as $S$. porcus. After detailed analysis we found that it does not belong to this species and possesses the following features which are typical for $S$. notata (see Fig. 1): no skin flaps above the eyes (in $S$. porcus there is a large skin flap above each eye), larger scales - a total of 48 between the gill cover and tail base (in $S$. porcus they are usually more than 60 ), five scales between the last soft ray of the dorsal fin and the lateral line (vs. 6-7 in S. porcus), and presence of a black blotch in the middle of the first dorsal fin (vs. no black blotch in S. porcus). All these features clearly point that the studied specimen belongs to the species $S$. notata. It possesses small differences in some of the body proportions compared to the studied material of the same species by Akalin et al. (2011) originating from the Aegean Sea near Iznik (see Table 1). It has somehow longer snout - prO in \% of $\mathrm{S} 1$ is 11.52 vs.
6.38-9.75. The eyes are smaller - do in \% of S1 is 9.79 vs. 13.42-15.63 and the distance between them is also slightly smaller - io in \% of S1 is 4.51 vs. $4.54-6.29$. Postdorsal distance is longer - poD in \% of Sl is 13.92 in the studied specimen vs. 7.24-11.11 in the Aegean Sea material. It is difficult to explain the obtained differences in the morphology but they are probably due to some distinctions in the measurement approach rather than taxonomic issue.

Although the ichthyofauna of the Bulgarian Black Sea coast is comparatively well investigated (Drensky, 1923; Guéorguiev et al., 1960; Stoyanov et al., 1963; Prodanov et al., 1998) there is no data about the presence of $S$. notata along it. The species was also not included in the overview works of Drensky (1951), Karapetkova \& Zivkov (1995), Zivkov et al. (2006) and Stefanov (2007). The studied specimen is the first and up to now the only record of $S$. notata in the Bulgarian sector of the Black Sea. The fact that the specimen was caught on 12 May 1926 makes it the first record in the Black Sea. As it was mentioned above, the oldest record of this species until now was known from 1930 near Gelendzhik, Russia (see Svetovidov, 1964).

It would be interesting whether the species will be discovered in new areas along the Bulgarian coast of the Black Sea in the future or should be considered "extinct". According to us, it should be rather rare, but constant inhabitant in the area. S. notata is obviously a rare 
Table 1: Body proportions of S. notata from Izmir Bay, Aegean Sea published by Akalin et al. (2011) and the specimen found in the ichthyological collections of NMNHS (values are range and in parentheses is mean).

Acronyms for the measurements used in the table are as follows: $\mathrm{Tl}$ - total length, $\mathrm{Sl}$ - standard length, lc - head length, $\mathrm{pD}_{1}$ - predorsal distance, $\mathrm{poD}$ - postdorsal distance, $\mathrm{pA}$ - preanal distance, $1 \mathrm{pc}$ - length of caudal peduncle, $1 \mathrm{D}_{1+2}$ - length of the base of both dorsal fins, $1 \mathrm{~A}$ - length of anal fin base, $\mathrm{H}$ - maximum body depth, $\mathrm{h}$ - least depth of caudal peduncle, prO - preorbital distance, do - horizontal diameter of eye, poO - postorbital distance, io - interorbital distance.

$\begin{array}{lll}\begin{array}{l}\text { Locality } \\ \text { Source }\end{array} & \begin{array}{l}\text { Black Sea, near Burgas } \\ \text { Our data }\end{array} & \begin{array}{l}\text { Aegean Sea, near Izm } \\ \text { Akalin et al. (2011) }\end{array} \\ \mathrm{n} & 1 \mathrm{ad} . & 23 \mathrm{ad} . \\ \mathrm{Tl}[\mathrm{mm}] & 132.5 & 92-178(142.74) \\ \mathrm{S} 1[\mathrm{~mm}] & 104.2 & 70-140(110.91) \\ \mathrm{in} \% \text { of S1 } & & \\ \mathrm{lc} & & \\ \mathrm{pD} & 43.76 & 39.04-44.52(41.16) \\ \mathrm{poD} & 35.32 & - \\ \mathrm{pA} & 13.92 & 7.24-11.11(9.13) \\ \mathrm{lpc} & 65.26 & - \\ \mathrm{lD} & 24.66 & - \\ 1 \mathrm{~A} & 63.15 & - \\ \mathrm{H} & 14.39 & - \\ \mathrm{h} & 38.29 & 35.34-41.74 \\ \mathrm{prO} & 11.42 & 5.24-11.43(8.96) \\ \text { do } & 11.52 & 6.38-9.75(8.57) \\ \text { poO } & 9.79 & 13.42-15.63(14.91) \\ \text { io } & 23.80 & - \\ & 4.51 & 4.54-6.29(5.38)\end{array}$

species in the Black Sea and the Aegean Sea and it is qualified as "Vulnerable for Turkey" by Fricke et al. (2007). According to the authors, the species shows significant decline and should be high priority for conservation action.

\section{References}

Akalin S., İlhan D., Ünlüoğlu A., Tosunoğlu Z., Özaydin O. 2011 Length-weight relationship and metric-meristic characteristics of two scorpion fishes (Scorpaena notata and Scorpaena porcus) in İzmir Bay. Journal of Fisheries Sciences 5 (4): 291-299.

Bilecenoglu M., Taskavak E., Mater S., Kaya M. 2002 Checklist of the marine fishes of Turkey. Zootaxa 113: 1-194.
Drensky P. 1923 Contribution à l'etude des poisons de la Mer Noire, récoltés sur les côtes bulgares. Spisanie na Balgarskata akademia na naukite 25: 59-12. (In Bulgarian)

Drensky P. 1951 Ribite v Balgaria [Fishes of Bulgaria]. Fauna of Bulgaria, Vol. 2. BAS, Sofia, 270 pp. (In Bulgarian)

Eschmayer W.N. 1969 A systematic review of the scorpionfishes of the Atlantic Ocean (Pisces: Scorpaenidae). Occasional Papers of California Academy of Sciences 79: 1-130.

Fricke R., Bilecenoglu M., Sari H.M. 2007 Annotated checklist of fish and lamprey species (Gnathostomata and Petromyzontomorphi) of Turkey, including a Red List of threatened and declining species. Stuttgarter Beiträge zur Naturkunde Serie A (Biologie) 706: 1-169. 
Fricke R., Eschmeyer W.N., Van der Laan R. (eds) 2021 Eschmeyer's catalog of fishes: genera, species, references. Electronic version accessed 27 February 2021.

Guéorguiev G., Alexandrova K., Nikoloff D.Ch. 1960 Observations sur la reprodution des poissons de long du littoral Bulgare de la Mer Noire. Bulletin de l'Institut de Zoologie 9: 255-292. (In Bulgarian)

Hureau J.C., Litvinenko N.I. 1986 Scorpaenidae. In: Whitehead P.J.P., Bauchot M.-L., Hureau J.-C., Nielsen J., Tortonese E. (eds), Fishes of the northeastern Atlantic and the Mediterranean. Vol. 3. UNESCO, Paris, 1211-1229.

Karapetkova M., Zivkov M. 1995 Ribite v Balgaria [The fishes of Bulgaria]. Gealibris, Sofia, 246 pp. (In Bulgarian)

Kottelat M., Freyhof J. 2007 Handbook of European Freshwater Fishes. Kottelat, Cornol Switzerland and Freyhof, Berlin. 646 pp.

Maximov V., Zaharia T. 2010 Demersal ichthyofauna of the Romanian Black Sea area. Muzeul Olteniei Craiova. Studii şi comunicări. Ştiinţele Naturii 26 (2): 239-246.

Muñoz M., Sàbat M., Vila S., Casadevall M. 2005 Annual reproductive cycle and fecundity of Scorpaena notata (Teleostei: Scorpaenidae). Scientia Marina 68 (4): 555-562.

Prodanov K., Dencheva K., Ivanov L. 1998 Fish of the Bulgarian Coastal Waters. In: Maine C. (ed.), Bul- garian Biological Diversity. Conservation Status and Needs Assessment. Vol. I \& II, 375-393.

Stefanov T. 2007 Species diversity and distribution of fishes in Bulgaria. In: Popov A., Fet V. (eds), Ecology and Biogeography of Bulgaria. Springer, 109139.

Stoyanov S., Gueorguiev G., Ivanov L., Hristov D., Kolarov P., Alexandrova K., Karapetkova M. 1963 Ribite $v$ Cherno more [The fishes of the Black Sea]. Varna, 246 pp. (In Bulgarian)

Svetovidov A.N. 1964 Ribyi Chernogo moria [The fishes of the Black Sea]. Nauka Publishers, Moscow, Leningrad, 525 pp. (In Russian)

Vasil'eva E.D. 2007 Fish of the Black Sea. Key to Marine, Brackish-water, Euryhaline, and Anadromous species with Color Illustrations Collected by S.V. Bogorodsky. VNIRO Publishing, 238 pp. (In Russian)

Yankova M., Pavlov D., Ivanova P., Karpova E., Boltachev A., Öztürk B., Bat L., Oral M., Mgeladze M. 2014 Marine fishes in the Black Sea: recent conservation status. Mediterranean Marine Science 15 (2): 366-379.

Zivkov M., Prodanov K., Trichkova T., Raikova-Petrova G., Ivanova P. 2006 Fishes in Bulgaria: research priorities, conservation and sustainable use. In: Petrova A. (ed.), Current state of Bulgarian biodiversity - problems and perspectives. Bulgarian Bioplatform, Sofia, 247-281. (In Bulgarian) 